\title{
Tsafon
}

Revue d'études juives du Nord

77 | 2019

Contribution à l'histoire des traductions juives de la Bible hébraïque

\section{Antijudaïsme et antisémitisme en Algérie coloniale,} 1830-1962

\section{Danielle Delmaire}

\section{OpenEdition}

\section{Journals}

Édition électronique

URL : https://journals.openedition.org/tsafon/2136

DOI : $10.4000 /$ tsafon. 2136

ISSN : 2609-6420

Éditeur

Association Jean-Marie Delmaire

Édition imprimée

Date de publication : 1 septembre 2019

Pagination : 176-177

ISSN : $1149-6630$

\section{Référence électronique}

Danielle Delmaire, «Antijudaïsme et antisémitisme en Algérie coloniale, 1830-1962 », Tsafon [En ligne], 77 | 2019, mis en ligne le 09 septembre 2019, consulté le 24 juin 2021. URL : http:// journals.openedition.org/tsafon/2136; DOI : https://doi.org/10.4000/tsafon.2136

Ce document a été généré automatiquement le 24 juin 2021.

Tsafon. Revues d'études juives du Nord 


\title{
Antijudaïsme et antisémitisme en Algérie coloniale, 1830-1962
}

\author{
Danielle Delmaire
}

\section{RÉFÉRENCE}

Aix-en-Provence, Presses Universitaires de Provence, , 351 p., $26 €$.

1 Maître de conférences honoraire à l'ÉSPÉ (École supérieure du professorat et de l'éducation) de l'Université Aix-Marseille, Geneviève Dermenjian est désormais connue pour ses nombreux travaux sur les communautés juives d'Algérie et sur l'antisémitisme qui sévissait dans cette colonie française. Son dernier ouvrage, très complet, reprend et augmente ses connaissances sur l'antijudaïsme et l'antisémitisme dans l'Algérie depuis l'arrivée des Français en 1830 (par la guerre) jusqu'à leur départ en 1962 (toujours par la guerre).

2 Après une introduction où les termes d'antijudaïsme et antisémitisme sont définis bien distinctement : le premier d'ordre religieux, le second d'ordre racial, économique et social, l'étude se présente en trois parties : l'histoire de l'antisémitisme en Algérie, dès avant même la colonisation, une anthropologique sur les différentes composantes de la population en Algérie coloniale, l'exposé des théories et doctrines antisémites à partir de diverse sources.

3 La présence juive est bien antérieure à l'arrivée des Français et les juifs sont considérés comme des "indigènes " par les premiers colonisateurs jusqu'à ce que le décret Crémieux (1870) les émancipe et les extrait de l'indigénat pour les intégrer dans la nation française. Leur européanisation commence donc dans le dernier quart du XIXe siècle et se trouve accélérée par l'implantation des écoles de l'Alliance israélite universelle. Désormais les juifs sont pris en étau entre les Européens, dont une partie se montre antisémite, et les indigènes musulmans encore influencés par la dhimmitude qui relègue les juifs à un rang inférieur. Or il se trouve d'une part des juifs, établis depuis des siècles en Algérie, très proches des « indigènes » musulmans et d'autre part 
des juifs sortis de l'indigénat par européanisation ou bien parmi les Européens venus coloniser l'Algérie. Durant la Seconde Guerre mondiale, le décret Crémieux fut aboli par le Gouvernement de Vichy et maintenu quelques mois encore par le gouvernement d'Alger, à la grande déception des nombreux juifs résistants. Dans l'Algérie coloniale, les juifs ont donc subi des exactions des deux côtés de la société. Les pogroms qui détruisent les quartiers sont souvent initiés par des Européens mais activement pratiqués par la populace européenne et musulmane.

historique de la première partie, Geneviève Dermenjian insiste sur les périodes de grande crise antisémite : durant les années 1890 avec le fort écho, en arrière fond, de l'affaire Dreyfus et pendant lesquelles les émules de Edouard Drumont et Max Régis sont nombreux et violents chez les Européens; puis durant les années 1930 avec le contexte tout aussi violent de la montée du nazisme en Allemagne, voire en Europe et en France. Les grands pogroms, dont celui de Constantine en 1934, se situent durant ces années. La période de la guerre légalise l'antisémitisme et correspond à l'ouverture de camps dans le sud algérien où bien des juifs ont souffert de maltraitance. Quant à la période de la guerre d'indépendance, la situation ne s'améliore guère. Majoritairement solidaires des colons partisans de l'Algérie française, les juifs n'en sont pas moins approchés par le FLN qui leur promet un monde meilleur dans une Algérie musulmane et indépendante. Peu nombreux sont ceux qui y croient.

5 La seconde partie étudie les différentes populations de l'Algérie coloniale et expose la diversité des milieux sociaux comme la bourgeoisie européenne dans laquelle se fondent peu à peu des familles juives mais aussi musulmanes, même si celles-ci subissent encore le statut de l'indigénat. Toutefois, si l'antisémitisme pénètre dans la majorité des couches sociales aisées ou pauvres, il se trouve toujours des personnalités ou des individus, des voisins qui renoncent à la stigmatisation des juifs. En définitive, il est bien difficile rappelle Geneviève Dermenjian de circonscrire la haine des juifs à tel ou tel groupe social. C'est d'ailleurs ce qu'écrivait le spécialiste de l'histoire de l'Algérie, Benjamin Stora (qui a préfacé l'ouvrage), dans ses souvenirs de Constantine (Les Clés retrouvées. Une enfance juive à Constantine, Stock, 2015) où sa famille, d'origine modeste, fréquentait les voisins arabes. Et pourtant c'est à Constantine que se déroule le plus grand pogrom meurtrier en août 1934.

6 La troisième et dernière partie présente les théories et les doctrines antisémites. Ce sont les pages les plus originales et les plus novatrices de l'ouvrage. L'auteur scrute les fêtes et les manifestations, analyse le langage et le vocabulaire, surtout celui de la presse et des tracts, pour déceler les mécanismes de la pensée antisémite. Les pages les plus impressionnantes sont celles qui reproduisent et commentent les caricatures qui appartiennent majoritairement aux deux décennies les plus virulentes contre les juifs : 1890 et 1930. Les clichés les plus éculés envahissent les pages de ces publications. Rien d'orignal, en vérité, n'est à retirer de cette propagande antisémite par la caricature. On y trouve les insectes malfaisants, les poux et autres araignées, les mêmes personnalités ciblées comme Dreyfus, Léon Blum ou son ministre Jean Zay.

7 En fin d'ouvrage, une abondante bibliographie et la liste des sources (archives, mais aussi la presse et la littérature d'époque) renseignent le lecteur.

8 Si l'ouvrage est à lire, on peut toutefois regretter quelques redondances dues au plan choisi, notamment en ce qui concerne les pogroms. 